Article

\title{
Regional Inclusive Development: An Assessment of Russian Regions
}

\author{
Elena Rytova ${ }^{1}$, Svetlana Gutman ${ }^{1, * \mathbb{D}}$ and Cristina Sousa ${ }^{2} \mathbb{D}$ \\ 1 Institute of Industrial Management, Economics and Trade, Peter the Great Saint-Petersburg Polytechnic \\ University, 195251 St. Petersburg, Russia; rytova_ev@spbstu.ru \\ 2 Iscte-Instituto Universitário de Lisboa, DINAMIA'CET-Iscte, 1649-026 Lisbon, Portugal; \\ cristina.sousa@iscte-iul.pt \\ * Correspondence: sgutman@spbstu.ru
}

Citation: Rytova, E.; Gutman, S.; Sousa, C. Regional Inclusive Development: An Assessment of Russian Regions. Sustainability 2021, 13, 5773. https://doi.org/10.3390/ su13115773

Academic Editor: Alan Randall

Received: 28 March 2021

Accepted: 15 May 2021

Published: 21 May 2021

Publisher's Note: MDPI stays neutral with regard to jurisdictional claims in published maps and institutional affiliations.

Copyright: (c) 2021 by the authors. Licensee MDPI, Basel, Switzerland. This article is an open access article distributed under the terms and conditions of the Creative Commons Attribution (CC BY) license (https:// creativecommons.org/licenses/by/ $4.0 /)$.

\begin{abstract}
The concept of inclusive development is gaining momentum in both the academic and policy-making arenas. There are a plethora of definitions and several indicators with which to monitor its progress at the national level. However, the regional level has been relatively overlooked in the analyses carried out by academics. This is particularly serious for large countries marked by deep regional disparities. The aim of this paper is to address this gap by proposing and applying a framework to assess inclusive development at the regional level. Drawing on a critical analysis of the concept and existing indexes, the paper proposes an index of Regional Inclusive Development and applies it to the regions of the Russian Federation. Moreover, it compares the suggested index with established indicators of regional socio-economic development, namely quality of life and gross product. The results support the idea that at the regional level, there is a significant correlation and interdependence between all dimensions of the sustainable development concept—environment, the economy, and society - and that inclusiveness should not be ignored or undervalued in the analysis of development processes. Furthermore, the results show significant differences in the positioning of the regions in terms of the inclusive development rankings as compared to their positions in the quality of life and gross product rankings. The results also reveal small interregional differences among Russian regions, which are unexpected given the size of the country.
\end{abstract}

Keywords: inclusive development; inclusive growth; region; Russia; Eurasia; regional inclusive development index; WEF inclusive development index

\section{Introduction}

Inclusive, or socially oriented, economic growth, which is enjoyed by the entire population, has recently become one of the most popular concepts (ideas) in development policies, as well as a central theme in the documents of international and supranational organisations (e.g., the International Monetary Fund (IMF), Organization for Economic Cooperation and Development (OECD), European Bank for Reconstruction and Development (EBRD), World Bank). Its popularity can be largely explained by the scale and impact of inequality in contemporary societies.

The rise of inequality in income and wealth distribution that characterises our societies constitutes the main subject of recent best sellers in Economics, namely Capital in the Twenty-First Century (T. Piketty, 2014), Plutocrats (C. Freeland, 2013) and The Price of Inequality (J. Stiglitz, 2013). Both scholars and international organisations warn of the dangers of this increase in inequality and advocate for policies that may reverse this trend. For example, the World Economic Forum (WEF) holds that the growth of inequality stems from the priority given to economic growth over social justice in the last decades, which has 'forced governments to miss a beneficial cycle in which growth is enhanced by wider distribution and generated without undue pressure on the environment or burdening future generations' [1]. This critical view has recently led several scholars [2-4] and international 
organisations (such as the WEF [1]) to question the centrality of economic growth and gross domestic product (GDP) in the analysis of the progress of nations, claiming that using GDP as a key economic indicator is ineffective. In fact, GDP only reflects the current production of goods and services, neglecting the extent to which the economy contributes to broader socio-economic progress, job opportunities, economic security, and quality of life. The emergence of the idea of inclusive development/growth is on a similar path to that of development generally and the human development and sustainable development approaches in particular [5]. The concept of inclusive development, similar to the concept of sustainable development, highlights the social and environmental dimensions. Inclusive development emphasises future generations instead of current ones [5] and is related to inclusiveness and an equitable division of the benefits of economic growth among all members of society, particularly the most excluded groups [6].

After the 2008-2009 crisis, it became clear that public policies should encourage inclusive growth. A series of reports were published (e.g., the final report of the Royal Society of Arts (RSA) Inclusive Growth Commission and reports by the Joseph Rowntree Foundation $(J R F)$ ), and research centers were established (e.g., the Inclusive Growth Analysis Unit (IGAU) at the University of Manchester). In 2008, the World Bank published 'The growth report: Strategies for sustained growth and inclusive development', which identified key factors and forms of political leverage that could help countries achieve high, sustainable, and inclusive growth [7]. In 2012, under the auspices of the United Nations (UN) Conference on Sustainable Development (Rio + 20), sustainability and inclusion have seen their centrality increase in international fora and processes [8]. This is visible in the World Bank discourse and in the statement that inclusive green growth is the pathway to sustainable development [8]. Later, inclusive growth was included in the UN Sustainable Development Goals (SDGs), which were adopted in 2015. In this international context, unsurprisingly, the policies of several countries have begun to make reference to inclusive development. For example, in 2015, 'inclusive growth' became one of the main goals of the Scottish government [9].

As a result of this increased centrality of inclusiveness in economic development, in 2018, the WEF presented an inclusive development index, which includes, in addition to GDP, another eleven key performance indicators characterising a country's general standard of living and the equality of all segments of the population [1]. This index recognises that the main goal of public development policies should be the achievement of sustainable, comprehensive progress, accompanied by the growth of the population's income, together with the growth of economic opportunities, economic security, and quality of life, not only the growth of GDP. The basis for calculating the index was the WEF's Inclusive Growth Policy (2015), as well as the Inclusive Growth and Development Report (2017) [10]. The main objective of the report was to make practical recommendations, namely for institutional frameworks and conditions in 15 inclusive growth policy areas, for the authorities of various countries and other stakeholders in developing a strategy to achieve a synergistic effect in the form of economic growth and improved living standards. To sum up, the WEF report includes policy recommendations and benchmarks for countries, aiming to provide national leadership with the practical tools necessary to transform the pursuit of inclusive growth into a practical and measurable action plan [1].

The relevance and usefulness of the index and the report can be illustrated with the case of Russia, which is a country that will be the subject of empirical analysis in this article. Russia ranked 19th among emerging countries on the inclusive development index. Even with the low poverty level in Russia, inequality is very high, and carbon emissions per dollar earned in GDP are among the highest in the group. The WEF report records a rapid decrease of the number of poor people in the first decade of the twenty-first century in response to the country's rapid economic growth, as well as the strong growth of income among the bottom $40 \%$, indicating that such growth could be called inclusive. However, halting reforms aimed at improving green investment, diversifying the economy and addressing infrastructure problems jeopardises past successes in terms of inclusive 
growth and social gains in recent years. On average, Russia's median standard of living is quite high compared to other economies in transition, and the poverty rate is low by the standards of non-developed countries [11]. Unemployment is also relatively low, although many are forced to work in the informal sector. The education system is fairly universal and accessible, although its quality must be improved to face the realities of a rapidly changing economy [12]. The financial sector is another area for improvement, especially in terms of small and medium-sized enterprises' financing [13]. Improving the progressivity of taxation and expanding social protection can also improve Russia's ability to provide inclusive (comprehensive) growth, according to the WEF report.

All initiatives mentioned above relate to the inclusive development of countries. However, it is clear that large countries could be characterised by a significant differentiation in economic development and living standards across regions [14-16]. There is evidence of the growing of political and economic importance of subnational scales, namely cityregions $[15,17]$. Despite the acknowledgement of intra-country disparities, surprisingly, national policymakers and international organisations have devoted less attention to inclusive development at the subnational level, although some important initiatives focused on cities have emerged (e.g., the OECD's 'Inclusive growth in cities' program, launched in 2016; The UN's 'New urban agenda', launched in 2016 [18]; the 2017 World Bank's paper on 'inclusive urbanisation', in which the Philippines were used as an example [19]; and the inclusive growth program that has been adopted and implemented in UK cities such as Manchester [20] and Leeds [21]). Still, no international body has proposed a regional inclusive development index.

The scant attention paid to the regional scale is also felt in the academy, where the discussions and analyses tend to be focused on the national level, as will be shown in the next section. This paper contributes to filling this gap in the extant research by studying the degree of inclusive development at the regional level. To do so, drawing on the existing literature and indexes (Section 2), it proposes a regional inclusive development index (Section 3) and computes it for all the regions of the Russian Federation (Section 4). The Russian Federation is a good empirical setting due to the fact that is a large country with high regional heterogeneity in terms of human and sustainable development $[14,16]$.

\section{Literature Review}

This section provides a critical analysis of the definitions and indicators of inclusive development offered by academics (the scientific literature) and governmental agencies, as well as by international and multilateral institutions (the grey literature).

\subsection{Academic Literature}

The scientific literature provides both conceptual and theoretical papers and methodological/empirical insights (based on both qualitative and quantitative methods).

Academic papers provide several definitions of inclusive growth/development. Among them, it is possible to highlight the following:

"development that includes marginalized people, sectors and countries in social, political and economic processes for increased human well-being, social and environmental sustainability, and empowerment. Inclusive development is an adaptive learning process, which responds to change and new risks of exclusion and marginalization." [5] (p. 546)

"growth that not only creates new economic opportunities, but also one that ensures equal access to the opportunities created for all segments of society, particularly for the poor." [22] (p. 12)

One question that emerges from the academic discussion is that of the trade-off between economic efficiency and social justice/fairness. Gupta, Pouw, and Ros-Tonen [5] trace the origins of the concept of inclusive development and conclude that its emergence is a reaction to the overly heavy focus on neo-liberalism, which has led to an excessive 
focus on efficiency at the cost of an increase in inequality and, thus, the creation of new divides in society. The authors conclude that inclusive development emphasises the social and ecological aspects of sustainable development, focussing on the current generation. They also argue that its promotion demands active public policy steering from the local to the global levels, which creates the conditions for adaptive learning and the empowerment of marginalised people. Adopting a different perspective, a paper [23] that examines the definitions used by both governmental and non-governmental organisations concludes that inclusive growth (IG) ceases to be a trade-off between fairness and efficiency; instead, increased equity also leads to increased efficiency.

Some empirical studies attempt to identify the causes of the growth of inequality and policies to address it. This is in the line of Picketty's analysis of the process of increasing inequality [24]. At this level, one study [25] identified four key areas that decrease income inequality in both developed and developing economies: (i) technological change-oriented skills; (ii) the improvement of educational systems; (iii) the consolidation of globalisation; and (iv) labor market reforms.

Another set of papers reflects on the determinants of IG. For example, [26] examines the impact of human capital on economic growth and development. It shows opportunities to achieve inclusiveness in economic systems through the establishment of special institutions to support the development of human capital, which contributes to the qualitative reproduction of socio-economic benefits.

Methodological and empirical studies describe approaches to index or indicator system development to measure inclusive growth. One paper [27] presents a review of indicators for measuring a country's inclusive growth proposed by various authors and international organisations. The author concludes that a unified approach to assessing inclusive growth would allow countries to identify the shortcomings of the existing economic growth model, specifically its limitations in terms of solving various social problems, and take certain measures to overcome them.

Some empirical studies address IG issues at the national level. For example, [28] suggests an approach to measuring inclusive growth in the Philippines. The authors define growth as inclusive if it increases the functioning of social opportunities, which depends on (i) the average opportunities available to the population and (ii) how these opportunities are distributed among the population. In addition, the study develops an index of opportunities that includes employment (including by gender), education, health, and basic infrastructure (electricity, pure drinking water, and sanitation). Another study [29] aimed to measure inclusive growth in Pakistan, as well as its determinants. It employed the methodology developed by the Asian Development Bank, using weights for various indicators. In addition, [30] uses principal component analysis to calculate an inclusive growth index in Tunisia and shows a reduction of its value between 1980 and 2017. The study [31], considering Nigeria for the period from 1980 to 2014, shows that access to electricity and transport infrastructure leads to inclusive growth and that access to ICT reduces poverty.

It is also possible to find certain studies that consider and compare a set of countries. One paper [32] explores the links between economic competitiveness and inclusive development in 101 economies based on the data presented in the 2018 WEF report. Another paper [33] analyses differences in the European Union (EU) countries, clustering them using three indicators: the global competitiveness index, inclusive development index, and human capital index. As a result of the analysis, countries from different geographical regions (i.e., Eastern or Central Europe) or economic groups (i.e., advanced or emerging countries) were not placed into the same clusters, which highlights the differences between EU countries at the regional/economic group level. In [34], an integrated index of inclusive growth at the country level was created to measure the contribution to inclusive growth of Bangladesh, Cambodia, India, Indonesia, the Philippines, and Uzbekistan. Finally, the authors of [35] analyse countries from Central and Eastern Europe (CEE) to determine their levels of inclusive growth. The paper assumes that CEE countries are socially and 
economically heterogeneous and have different levels of sustainable development. Using the principal component method and multivariate analysis, that project shows that Estonia, Slovenia, and the Czech Republic have the highest levels of inclusive growth, while Bulgaria and Romania have the lowest.

Lastly, scientific research has also begun to address subnational scales, mostly at the city level. For example, [36] proposes a system of indicators with which to measure the inclusive growth of eleven coastal provinces and cities in China from 2000 to 2015, concluding that the different regions exhibit large differences in the level of inclusive development. It is evident that the eastern coastal regions have higher rates of development than the northern and southern coastal regions. Another paper [37] proposes an integrated function (model) with which to assess the levels of inclusive green growth in 285 Chinese cities from 2003 to 2015 and shows that the main barrier to comprehensive green growth is the level of technological innovation, which is not consistent with China's level of green growth. Paper [36] reviews the indicators that have been developed to help UK cities formulate and measure inclusive growth and summarises progress in inclusive growth for Greater Manchester.

To the best of our knowledge, only four papers address the topic of inclusive development at the regional scale, all considering Russian regions. Paper [38] investigates the concept of inclusive growth and development and the key indicators of efficiency. Particular attention is paid to the WEF methodology, an adapted version of which was applied to study 26 regions of Russia from 2012 to 2017. The authors show strong differences between the regions, with the Moscow Region at the top of the rankings (average value of 4.13) and the Irkutsk Region in the bottom (average value of 2.31). The study also shows that in most regions, inclusive development worsened due to the growth of poverty, the rise in government debt, the deterioration of the environmental situation, and the population's low income. Papers $[39,40]$ analyse the inclusive development of 16 Russian resource regions, using an adapted version of the indicators proposed by the Asian Development Bank and considering four blocks-personal income and inequality, access to the health system, housing conditions, and access to infrastructure-which are integrated to compute an index of economic growth inclusiveness. The authors suggest that the position of each region in the rankings can be explained by the effectiveness of regional policy and the particularities of the development of mineral resources. A more recent study [41] develops a regional inclusive development index, which is close to the proposal of the Asian Development Bank, based on four blocks: economic growth and its opportunities, poverty and inequality, social inclusion intergenerational equality, and sustainability. This study shows a gap of 2.6 between the most inclusive region (Moscow) and the least inclusive one (the Republic of Tuva). It also shows that rich regions are not always inclusive regions.

\subsection{Grey Literature}

The grey literature, developed by international and multilateral institutions, as well as national governments, also provides useful insights into the concept and approaches to analysing and assessing inclusive growth/development.

The World Bank [7] defines IG as sustainable growth that is spread throughout all sectors of economy, involving most of the labor force, and characterised by equal opportunities in terms of access to the market and resources. The World Bank also notes that new employment opportunities must be created, and there is a need to focus on a preliminary analysis of the opportunities for and threats to sustainable growth, poverty reduction, and increased productivity. In line with this vision, the OECD [42] stresses the importance of inclusive growth in raising living standards and promoting a more even (fair) distribution of material and intangible benefits between various social groups, including youth, migrants, women and pensioners, to increase their wellbeing. However, neither the World Bank nor the OECD offers an integrated approach to economic policy assessment, development and implementation. 
Conversely, the United Nations Development Programme (UNDP) [43] does not provide a clear concept of IG, but it does provide a description of a wide range of dimensions that should be taken into account in the assessment of IG, from sustainable environmental development (i.e., climate change, pollution, a lack of energy and natural disasters) to rural communities, including household incomes and health, education, and recreation costs. Accordingly, the basis of IG is equality of opportunities and the participation of all in growth (especially the poor and unemployed).

The European Commission understands IG as growth that includes the full use of labor potential, the reduction of poverty and its consequences, the development of social inclusion, and the elimination of regional imbalances [44]. Inclusive growth means empowering people through high levels of employment, investment in skills, poverty alleviation and the modernisation of labor markets, training, and social protection systems. It proposes a set of indicators for analysis, which are combined into five groups without calculating the integral indicator.

The Asian Development Bank (ADB) [45] refers to IG as 'high, sustainable growth that not only creates and expands economic opportunities, but also provides equal access to these opportunities so that members of the society can participate and benefit from the growth and development of social protection to prevent extreme deprivation'. It proposes a set of indicators for IG analysis that are combined into seven groups without calculating the integral indicator. Thus, the ADB does not offer an integrated approach to the development and implementation of economic policies [46].

The Rockefeller Foundation [47,48] defines inclusive economies as those that expand opportunities for shared prosperity. It has developed a new structure that defines five pillars of an inclusive economy-equality, participation, stability, sustainability, and growth — and emphasises the idea that more inclusive economies are more equitable, participatory, growing, sustainable, and stable. Researchers from Brookings identified indicators for each pillar (about 100 indicators). The total score is calculated based on the average ratings for individual indicators for each of the five pillars.

The WEF not only provides a concept, a methodology with which to compute an inclusive development index but also an application of that methodology in a ranking exercise of 103 countries and an integrated approach to assist in the formulation of public policies to promote IG [1,49]. It holds that IG has the following characteristics: it exhibits productivity growth, provides the basis for the development of all sectors in the economy; provides opportunities for full and productive employment for the vast majority of the working-age population; and reduces poverty. The WEF proposes to assess the countries' economic policies on the basis of the composite IG index. For this purpose, the national indicators are grouped into three pillars: growth and development (GDP per capita, labor productivity, healthy life expectancy, and employment); inclusion (Gini coefficient for income and wealth, poverty level, and median income) and intergenerational equality and sustainability (adjusted net savings, carbon emission intensity of GDP, public debt, and demographic burden coefficient).

It is also possible to find some attempts to define and measure IG at a subnational level. The RSA's inclusive growth commission [50] provides both a concept and a measurement methodology, although it does not apply the proposed methodology to a specific set of territories. It offers a broad vision of IG as a form of growth that will allow a large number of people to both contribute to and benefit from economic growth, and it has identified four blocks of indicators for measuring IG across regions: skills and employment, living standards, entrepreneurship, and local capacity. The indicators include healthy life expectancy, the quality of private rental housing, participation in the labor market among various segments of the population, progress in work, the percentage of the workforce protected by employment rights, and a 'community confidence indicator'.

The Greater Manchester Combined Authority [51] holds that IG is a new model of sustainable economic growth-one based on the idea of a more cohesive, talented, and eco-friendly urban region, in which all residents can contribute to and benefit from sustain- 
able prosperity, as well as enjoying a good quality of life. The Joseph Rowntree Foundation proposes a tool with which to monitor inclusive growth based on the relationship between prosperity and economic inclusion (as an indicator of poverty), and it makes this information available for 39 Local Enterprise Partnerships (LEP) zones across England [52]. The Inclusive Growth Monitor is based on 18 publicly available indicators that have been grouped into two blocs - prosperity and economic inclusion-each containing nine indicators. The monitor focuses on economic outcomes rather than social and environmental indicators. The theme of economic inclusion addresses various aspects of poverty and related forms of economic damage, while the theme of prosperity addresses economic indicators or economic potential. Finally, the consultancy company PwC, in collaboration with the Demos think tank, has calculated an index for the Good Growth of Cities for the UK's largest cities [53]. The index is based on the ten categories that the public considers to be the most important from the point of view of economic wellbeing (employment, health, income, skills and abilities, housing, work-life balance, income distribution, transportation, environment, and startups). It ranks local authorities in accordance with their average score in six categories (prosperity, dynamics and opportunities, inclusiveness and equality, health, well-being and happiness, flexibility, and sustainability). Each category can be considered as a separate index. The indicators were proposed by researchers and refined after discussions with the Vibrant Economy Commission, Grant Thornton UK and general public feedback.

\subsection{Main Insights from the Literature Review and Research Questions}

All in all, the concept of inclusive development/growth emerged in 2010, in the aftermath of the global crisis, after the acknowledgement of stubborn economic and social inequalities. For now, there is no clear universal definition of inclusive growth/development. However, there is a consensus on the fact that it focusses on the well-being of all people in the current generation, stressing the social and distributional aspects of development.

The fact that several authors and studies use different definitions of the concept has implications not only for the conceptual clarity in the study of the process but also for the choice of variables that should be used in its empirical analysis. This is particularly visible when we analyse the grey literature but also when analysing some empirical studies. Consequently, thus far, there is no established set of data necessary to measure inclusive growth or inclusive development and monitor and assess the inclusive development policies and programs implemented in particular countries.

Moreover, studies tend to address the national level to discuss the concept of inclusive development and analyse it. It was possible to identify a small number of methodological proposals to measure inclusive development at the regional level and some empirical studies. The need for regional assessment is particularly acute in large countries, such as Russia.

This paper aims to study the degree of inclusive development at a regional level, focussing on a large country, the Russian Federation. It proposes a regional inclusive development index based on the WEF methodology and computes in an attempt to answer the following research questions: Is it possible to use the WEF methodology at the regional level? How is it possible to adapt this methodology based on the peculiarities of regional statistics? Previous research has not yet provided an adjusted net savings indicator at the regional level in Russia, so it is important to make the correct adaptation. In previous studies $[46,54,55]$, this problem was discussed, and various approaches were suggested to the calculation of adjusted net savings, all with several limitations. This paper proposes a new methodology based on a combination of the adjusted net savings theoretical concept and the Russian regional statistics. Can a regional inclusive development index be used to adjust regional development strategies and regional socio-economic policies? To the best of our knowledge, only one paper addresses the topic of inclusive development at the regional scale, resorting to the WEF methodology and applying it to study 26 regions of Russia [38]. This paper, beyond the difference in methodology, extends the analysis to 
all Russian regions. The correct comparison of regions is possible in this case, as well as making clusters based on management goals.

\section{Materials and Methods}

In this paper, we draw on the WEF methodology because this organisation provides not only a methodology with which to measure IG but also an integrated approach to assessing IG policies. In order to develop institutions and create an environment conducive to inclusive growth, the WEF experts believe that key and institutional indicators of inclusive development are important and propose an inclusive development index for nations based on twelve indicators organised into three groups (Figure 1) [10].

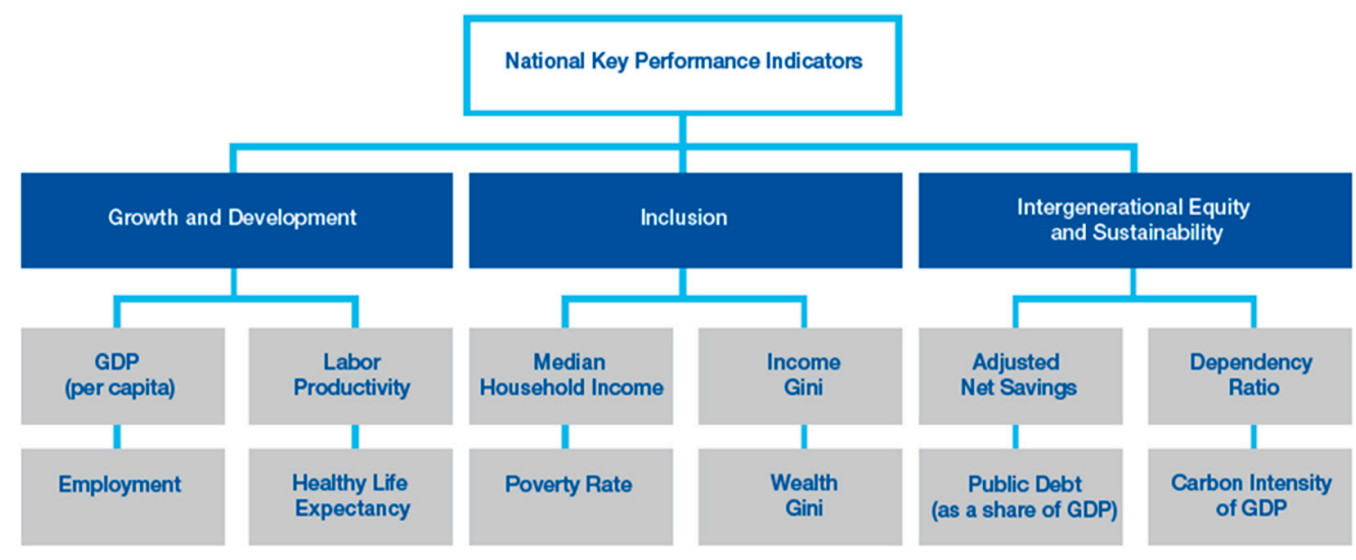

Figure 1. Components of the WEF Inclusive Development Index.

In order to calculate the indicator at the regional level, the WEF indicators were adapted to the regional statistical database of the Russian Federation. Consequently, the following indicators were used to calculate the index (Table 1):

Table 1. Adaptation of the WEF indicators to Russia's regional statistical base.

\begin{tabular}{|c|c|}
\hline WEF Indicators & Indicators for Russian Regions * \\
\hline \multicolumn{2}{|c|}{ Growth and Development Indicators } \\
\hline GDP per capita & $\begin{array}{l}\text { Gross Regional Product (GRP) } \\
\text { per capita, rubles }\end{array}$ \\
\hline Labor productivity-GDP per employee & $\begin{array}{c}\text { Productivity } \\
\text { (calculated according to Rosstat as the ratio of } \\
\text { GRP in millions of rubles to the average annual } \\
\text { number of employed in the region in } \\
\text { thousands of people) }\end{array}$ \\
\hline Healthy life expectancy & Healthy life expectancy, years ** \\
\hline Employment & $\begin{array}{l}\text { Average annual number of employed, } \\
\text { thousands of people }\end{array}$ \\
\hline \multicolumn{2}{|c|}{ Inclusion Indicators } \\
\hline Income stratification coefficient & Gini coefficient \\
\hline Poverty rate & $\begin{array}{l}\text { Poverty rate (share of the population with } \\
\text { incomes below the subsistence level), \% }\end{array}$ \\
\hline Society distribution stratification coefficient & Funds coefficient, times \\
\hline Median income & $\begin{array}{l}\text { Median per capita income (Me) (rubles } \\
\text { per month) }\end{array}$ \\
\hline
\end{tabular}


Table 1. Cont.

\begin{tabular}{cc}
\hline WEF Indicators & Indicators for Russian Regions * \\
\hline Intergenerational Equity and Sustainability Indicators \\
\hline Adjusted net savings & $\begin{array}{c}\text { Data absent from regional statistics } \\
\text { (calculation assumed) }\end{array}$ \\
\hline Carbon intensity of GDP & $\begin{array}{c}\text { Carbon intensity of GRP, tons per million } \\
\text { rubles (calculated according to Rosstat as the } \\
\text { ratio of the indicator 'Air emissions from } \\
\text { stationary sources, thousand tons' to GRP in } \\
\text { million rubles). Data on CO } \mathrm{C}_{2} \text { emissions absent } \\
\text { from regional statistics }\end{array}$ \\
\hline
\end{tabular}

\begin{tabular}{cc}
\hline Public debt & $\begin{array}{c}\text { Public debt volume, thousand rubles } \\
\text { (according to the Ministry of Finance of the } \\
\text { Russian Federation as of 1 January 2019) })^{* * *}\end{array}$ \\
\hline Dependency ratio & $\begin{array}{c}\text { Dependency ratio (non-productive people per } \\
1000 \text { people of working age) }\end{array}$
\end{tabular}

* According to the Russian Federation Federal State Statistics Service (Rosstat). ${ }^{* *}$ Indicator is calculated from 2018 as part of the national program. ${ }^{* *}$ The Ministry of Finance of the Russian Federation official website.

According to the WEF methodology, a set of absolute values of the presented indicators in each group is formed. Since the indicators are inherently different, they must be rationed to bring them into a comparable form. In addition, according to the WEF methodology, the definition area for the indicators is set from 0 to 7 . Two formulas were used to ration indicators from 0 to 7 .

If:

1. A high value of the indicator demonstrates a favorable situation in the region, then

$$
i=6 * \frac{\left(F \mid i-F_{\min }\right)}{\left(F_{\max }-F_{\min }\right)}+1
$$

2. A high value of the indicator demonstrates an unfavorable situation in the region, then

$$
i=-6 * \frac{\left(F \mid i-F_{\text {min }}\right)}{\left(F_{\text {max }}-F_{\text {min }}\right)}+7
$$

where $F i$ is the inclusion indicators for region $i$;

Fmin and Fmax are the minimum and maximum values of the indicator for the Russian Federation.

Then, the rationed values of the indicators are reduced into indices by group and then into an integral index. The arithmetic average of all indicators is used to form indices.

The most controversial step in calculating the inclusion index has become the definition of net adjusted savings. According to the calculation methodology, net adjusted savings (NAS), or genuine savings, are the result of a consistent correction in economic performance. The first step is to define the net domestic savings (NDS) as the difference between gross domestic savings (GDS) and the value of the consumption of fixed capital (CFC). In the second phase, net domestic savings increase by the amount of education expenses (EDE) and decrease by the amount of the depletion of natural resources (DPNR) and the damage from environmental pollution (DMGE) [54]:

$$
\mathrm{NAS}=(\mathrm{GDS}-\mathrm{CFC})+\mathrm{EDE}-\mathrm{DPNR}-\mathrm{DMGE} .
$$

The calculations of net-adjusted savings for particular countries show a huge divergence of traditional economic and environmental indicators; i.e., many countries are characterised by a situation in which formal economic growth is accompanied by environmental degradation. In this case, the environmental correction can lead to a significant reduction in 
traditional economic indicators to the point of negative values for their growth (as it was in Russia in 2000: with GDP growth of 9\%, the rate of genuine savings was negative, at -13\%). Currently, 'genuine savings' indicators are calculated by World Bank experts in more than 100 countries. These data are presented in the World Bank Environmental Directory.

It should be noted that the assessment of the genuine savings rate, in its current form and with the existing calculation methodology, is not feasible at the regional level. Obviously, the methodology for calculating the region's net adjusted savings indicator should be based on the availability of the regional-level statistical information needed to generate the genuine savings indicator, which is inherently an indicator of the level of national accounts.

The indicator of net-adjusted savings, or genuine savings, at the region level for the Russian Federation was studied in detail in 2012 as a cumulative environmental and economic index. The calculation of this index was not carried out by the state statistical agencies, and all methods used in calculating this integral indicator relate mainly to the national level. The problem with adapting this indicator to the regional level is that there is still no single methodology for regional assessment and information on a number of essential indicators is not collected.

In a proposal for an ecological-economic index for Russian regions [55], the indicator of net adjusted savings is regarded as a cumulative socio-economic-environmental index and defined as follows:

$$
\mathrm{NAS}=\mathrm{GF}-\mathrm{IME}-\mathrm{INR}-\mathrm{DEP}+\mathrm{RHC}+\mathrm{EPC}+\mathrm{SPNA}
$$

where GF is gross fixed capital formation, IME is investment in fixed assets related to mineral extraction, INR is the depletion of natural resources, DEP is damage from environmental pollution, RHC is the total costs to the region to develop and maintain human capital and potential, EPC is environmental protection costs, and SPNA is an assessment of specially protected natural areas. A negative value for this indicator suggests an unstable type of development in the region, which should lead to deterioration in the well-being of the entire population, but official statistics lack a substantial number of indicators, such as the depletion of natural resources and the assessment of protected natural areas.

Due to the current lack of a significant number of the necessary statistics, Bekish, E.L., in 'Net savings as an indicator of the sustainable development of various types of regions in Russia', proposes applying a simplified formula for assessing net adjusted savings [56]:

$$
\mathrm{NAS}=\mathrm{GRP}-\mathrm{C}-\mathrm{CO}_{2}+\mathrm{E}
$$

where NAS is net adjusted savings (net savings), GRP is gross regional product, $C$ is household consumption, $\mathrm{CO}_{2}$ is carbon dioxide emissions, and $\mathrm{E}$ is cost of education.

The presented approach seems extremely simplistic. It should be noted that gross domestic savings is a statistical indicator that is calculated as the difference between GDP and total private and public consumption, and it is expressed in monetary units or as a percentage of GDP. The GDP on expenditures is formed by summing up the costs of all economic entities for the purchase of final products. The calculations involve the consumer expenditures of the population-all expenses of the citizens to buy clothes, products, services, and durable goods, as well as private investment-any net investment or increase in durable capital goods (buildings, machinery, and equipment). When calculating GDP, the term 'private investments' refers only to those that form capital; public procurement is money spent by government agencies and authorities to buy goods and purchase services. In this case, benefits (transfer payments) are not taken into account, because they are given free of charge, not in exchange for services or goods; net exports are the difference between exports and imports. Thus, the gross domestic savings rate, derived from deducting all economic entities expenditures on the purchase of final products from GDP, reflects the potential volume of national domestic and foreign investment. 
In a recent paper [53], the index was also adapted to the regional level, taking into account the following considerations of this conclusion, and the following calculation method was formulated:

$$
\mathrm{NAS}=\mathrm{IRM}+\mathrm{InI}-\mathrm{NRC}-\mathrm{AE}-\mathrm{EI},
$$

where IRM is investments in modernisation and reconstruction, InI is budgetary investments in innovation, NRC is losses from the irrational use of resources (rental costs), AE is losses from air pollution, and EI is losses due to environmental reasons.

A negative value of GRS indicates that the capital investments and total capital of the region do not cover the losses caused by the production component of this capital due to its natural and social component. If GRS is positive, the total regional capital is increasing.

The logic of this approach stems from the fact that because the indicator of gross domestic savings, which is adjusted, reflects the potential volume of national domestic and foreign investments, then it is possible to use indicators of investments in fixed assets instead of an indicator of net savings, which represents the difference between gross savings and the depreciation (amortisation) of fixed assets, actually reflecting the volume of public and private investments in fixed assets, the volume of capital repairs and other investment costs. In this case, the logic of calculating savings at the regional level will not be broken. Therefore, net savings may be replaced with the total investment in modernisation and reconstruction (IMR). It is also obvious that the rental component, at the regional level, should be calculated not so much on the basis of production volumes (because this indicator is not indicative for each and every region) but rather on the volumes of consumption of non-renewable resources, primarily carbon (natural resource consumption, NRC). It is also necessary to substantiate the method of calculating investments in education at the regional level (it is appropriate to use the innovative investments indicator) and the extent of the harm to the environment and health, which are included in the genuine savings calculation.

Considering the above-mentioned methodologies with which to compute net adjusted savings, it was decided that the WEF methodology should be adapted to the available regional data. As in the previous study [57], the idea of adaptation is that net adjusted savings represent potential investments of the region and its accumulated human and physical capital, including intangible assets and less environmental damage. Consequently, three main blocks were included in the calculation of NAS:

1. Investment block, including investments in fixed assets, foreign direct investment in the region, research and development costs, education costs, and environmental costs.

2. Accumulated funds-fixed assets in the economy, less depreciation.

3. Environmental block. Since the block of environmental indicators is still poorly developed in Russian statistics, the performance indicators of two industries were chosen to assess adjustment for the environmental component: extractive production and pollution elimination. It is obvious that the shipment volume by the 'Extractive production' type of business is fundamentally a valuation of minerals extracted in the region, that is, it can be regarded as the volume of natural resource depletion. The shipment volume by the 'Water supply, water disposal, waste collection and disposal and pollution elimination activities' type of business represents the amount of funds spent on managing the pollution disposal process; it can be an indirect indicator of the damage caused to the environment.

Based on the above logic and with allowances for the available data, the following method of calculating the NAS indicator was chosen:

$$
\mathrm{NAS}=\mathrm{Inv}+(\mathrm{VFA}-\mathrm{D} * \mathrm{VFA})+\mathrm{FDI}+\mathrm{RaD}+\mathrm{Env}-\mathrm{Ext}-\mathrm{W}+\mathrm{Ed}
$$

where Inv is investments in fixed assets, in million rubles; VFA is fixed assets in the economy, in million rubles; D is depreciation degree of fixed assets, in percentage; FDI is foreign direct investment balance in the region, in million rubles; $\mathrm{RaD}$ is capital expenditures 
for research and development, in million rubles; Env is environmental protection costs, in million rubles; Ext is shipment volume by 'Extractive production', in million rubles; $\mathrm{W}$ is shipment volume by 'Water supply; water disposal, waste collection and disposal, pollution elimination activities', in million rubles, and Ed is the consolidated 'Education' budget expenditures of Russian federation entities, in million rubles.

Thus, using this formula, the value of net adjusted savings for the regions of the Russian Federation was calculated, which was then used in determining the inclusive development index for these Russian regions.

\section{Results}

The inclusive development index was calculated using the described methodology, consisting of an adaptation of the WEF methodology, and data from the Rosstat for 2017. The index calculation results for the 85 Russian regions are presented in Table 2, which also contains reference values for each region in the quality of life and gross regional product (GRP) rankings.

According to the WEF methodology, the index is determined within the interval $(0 ; 7)$. The maximum index value for the regions of Russia is 4.92 (Moscow), while the minimum is 2.9 (Krasnoyarsk Territory). The average value is 3.6, while 27 (31.7\%) Russian regions are in the range of 3.5 to 3.7 , that is, in the middle zone.

Comparing the rankings of the regions on the inclusive development index against more traditional indicators of growth, namely gross regional product, shows that economic prosperity and inclusive development do not always go hand in hand in Russian regions. This is clear if you consider the cases of Krasnodar and Krasnoyarsk, which rank high in terms of gross product but occupy the last positions in terms of inclusive development. Conversely, the Republic of Ingushetia, the Magadan Region, and the Kamchatka Territory have a poor performance in terms of gross product but rank high in terms of inclusive development. It is also visible that in several regions, there is a mismatch between quality of life and inclusive development (see the examples of Krasnodar Territory, Lipetsk Region, and the Republic of Ingushetia).

Considering the inclusive development index, five groups of regions were identified based on the level of inclusion: high (dark green on the map), above average (light green), medium (yellow), below average (orange), and low (red). Figure 2 shows that most of the country is below average in terms of inclusive development.



Figure 2. Map of inclusive development of Russian regions. 
Table 2. Inclusive development index for Russian regions in 2018 (assessment results).

\begin{tabular}{|c|c|c|c|c|c|}
\hline & \# $\operatorname{Reg} *$ & Index Value & Ranking & $\begin{array}{l}\text { For Reference: Quality } \\
\text { of Life Ranking }\end{array}$ & $\begin{array}{l}\text { For Reference: Regions } \\
\text { Ranking by GRP }\end{array}$ \\
\hline Moscow City & 18 & 4.92 & 1 & 1 & 1 \\
\hline $\begin{array}{l}\text { Yamalo-Nenets Autonomous } \\
\text { District }\end{array}$ & 63 & 4.40 & 2 & 12 & 6 \\
\hline Nenets Autonomous District & 22 & 4.33 & 3 & 67 & 58 \\
\hline $\begin{array}{l}\text { Khanty-Mansi Autonomous } \\
\text { District-Yugra }\end{array}$ & 62 & 4.06 & 4 & 8 & 3 \\
\hline Kamchatka Territory & 78 & 3.99 & 5 & 32 & 63 \\
\hline Murmansk Region & 26 & 3.97 & 6 & 36 & 43 \\
\hline Leningrad Region & 25 & 3.96 & 7 & 11 & 21 \\
\hline Kaliningrad Region & 24 & 3.95 & 8 & 10 & 45 \\
\hline St. Petersburg City & 29 & 3.95 & 9 & 2 & 5 \\
\hline Republic of Ingushetia & 39 & 3.91 & 10 & 82 & 84 \\
\hline Magadan Region & 82 & 3.90 & 11 & 35 & 73 \\
\hline Sakhalin Region & 83 & 3.88 & 12 & 46 & 20 \\
\hline Tver Region & 15 & 3.86 & 13 & 59 & 46 \\
\hline Republic of Chuvashia & 50 & 3.83 & 14 & 47 & 60 \\
\hline Vladimir Region & 3 & 3.83 & 15 & 34 & 47 \\
\hline Republic of Dagestan & 38 & 3.83 & 16 & 69 & 36 \\
\hline Kaluga Region & 6 & 3.81 & 17 & 21 & 44 \\
\hline Tula Region & 16 & 3.80 & 18 & 17 & 34 \\
\hline Kostroma Region & 7 & 3.79 & 19 & 60 & 71 \\
\hline $\begin{array}{l}\text { Chukotka Autonomous } \\
\text { District }\end{array}$ & 85 & 3.78 & 20 & 70 & 79 \\
\hline Republic of Crimea & 32 & 3.77 & 21 & 52 & 50 \\
\hline Tyumen Region & 61 & 3.75 & 22 & 14 & 2 \\
\hline Astrakhan Region & 34 & 3.75 & 23 & 56 & 41 \\
\hline Chelyabinsk Region & 64 & 3.73 & 24 & 23 & 13 \\
\hline Penza Region & 55 & 3.72 & 25 & 30 & 49 \\
\hline $\begin{array}{l}\text { Republic of North } \\
\text { Ossetia-Alania }\end{array}$ & 42 & 3.71 & 26 & 65 & 76 \\
\hline Yaroslavl Region & 17 & 3.71 & 27 & 27 & 40 \\
\hline Kursk Region & 8 & 3.69 & 28 & 15 & 48 \\
\hline Volgograd Region & 35 & 3.69 & 29 & 37 & 26 \\
\hline Moscow Region & 10 & 3.67 & 30 & 3 & 4 \\
\hline Republic of Karelia & 19 & 3.67 & 31 & 74 & 61 \\
\hline Ulyanovsk Region & 58 & 3.66 & 32 & 28 & 52 \\
\hline Republic of Kalmykia & 31 & 3.65 & 33 & 81 & 81 \\
\hline Republic of Chechnya & 43 & 3.64 & 34 & 71 & 70 \\
\hline Novgorod Region & 27 & 3.64 & 35 & 61 & 62 \\
\hline Tomsk Region & 74 & 3.64 & 36 & 51 & 39 \\
\hline Khabarovsk Region & 80 & 3.63 & 37 & 29 & 31 \\
\hline Primorsky Region & 79 & 3.62 & 38 & 50 & 27 \\
\hline Republic of Mordovia & 47 & 3.62 & 39 & 44 & 66 \\
\hline Kirov Region & 52 & 3.62 & 40 & 63 & 53 \\
\hline $\begin{array}{l}\text { Republic of } \\
\text { Kabardino-Balkaria }\end{array}$ & 40 & 3.60 & 41 & 76 & 75 \\
\hline Sevastopol City & 37 & 3.60 & 42 & 20 & 78 \\
\hline $\begin{array}{l}\text { Republic of } \\
\text { Karachay-Cherkessia }\end{array}$ & 41 & 3.60 & 43 & 84 & 80 \\
\hline Ivanovo Region & 5 & 3.59 & 44 & 48 & 69 \\
\hline
\end{tabular}


Table 2. Cont.

\begin{tabular}{|c|c|c|c|c|c|}
\hline & \# $\operatorname{Reg} *$ & Index Value & Ranking & $\begin{array}{l}\text { For Reference: Quality } \\
\text { of Life Ranking }\end{array}$ & $\begin{array}{l}\text { For Reference: Regions } \\
\text { Ranking by GRP }\end{array}$ \\
\hline Republic of Udmurtia & 49 & 3.58 & 45 & & 35 \\
\hline Stavropol Region & 44 & 3.56 & 46 & 22 & 29 \\
\hline Novosibirsk Region & 72 & 3.56 & 47 & 24 & 18 \\
\hline Irkutsk Region & 70 & 3.54 & 48 & 68 & 15 \\
\hline Samara Region & 56 & 3.53 & 49 & 18 & 12 \\
\hline Vologda Region & 23 & 3.51 & 50 & 62 & 37 \\
\hline Ryazan Region & 12 & 3.51 & 51 & 26 & 51 \\
\hline Saratov Region & 57 & 3.50 & 52 & 38 & 30 \\
\hline Arkhangelsk Region & 21 & 3.50 & 53 & 75 & 28 \\
\hline Republic of Tatarstan & 48 & 3.50 & 54 & 4 & 7 \\
\hline Pskov Region & 28 & 3.49 & 55 & 58 & 74 \\
\hline Tambov Region & 14 & 3.49 & 56 & 40 & 54 \\
\hline Republic of Khakassia & 67 & 3.48 & 57 & 55 & 64 \\
\hline Orel Region & 11 & 3.47 & 58 & 41 & 65 \\
\hline Bryansk Region & 2 & 3.46 & 59 & 49 & 55 \\
\hline Voronezh Region & 4 & 3.45 & 60 & 7 & 24 \\
\hline Jewish Autonomous Region & 84 & 3.41 & 61 & 78 & 83 \\
\hline Baikal Region & 77 & 3.41 & 62 & 83 & 56 \\
\hline Rostov Region & 36 & 3.41 & 63 & 19 & 14 \\
\hline Belgorod Region & 1 & 3.41 & 64 & 5 & 25 \\
\hline Nizhny Novgorod Region & 53 & 3.40 & 65 & 16 & 16 \\
\hline Perm Region & 51 & 3.36 & 66 & 42 & 17 \\
\hline Kurgan Region & 59 & 3.36 & 67 & 79 & 68 \\
\hline Republic of Adygea & 30 & 3.35 & 68 & 31 & 77 \\
\hline Smolensk Region & 13 & 3.35 & 69 & 39 & 57 \\
\hline Republic of Sakha (Yakutia) & 76 & 3.34 & 70 & 72 & 22 \\
\hline Republic of Komi & 20 & 3.33 & 71 & 64 & 33 \\
\hline Republic of Buryatia & 75 & 3.32 & 72 & 77 & 67 \\
\hline Republic of Altai & 65 & 3.31 & 73 & 80 & 85 \\
\hline Orenburg Region & 54 & 3.31 & 74 & 33 & 23 \\
\hline Omsk Region & 73 & 3.29 & 75 & 57 & 32 \\
\hline Republic of Tuva & 66 & 3.29 & 76 & 85 & 82 \\
\hline Altai Territory & 68 & 3.26 & 77 & 73 & 42 \\
\hline Sverdlovsk Region & 60 & 3.26 & 78 & 13 & 10 \\
\hline Republic of Mari El & 46 & 3.25 & 79 & 66 & 72 \\
\hline Republic of Bashkortostan & 45 & 3.25 & 80 & 25 & 11 \\
\hline Lipetsk Region & 9 & 3.24 & 81 & 9 & 38 \\
\hline Amur Region & 81 & 3.18 & 82 & 53 & 59 \\
\hline Kemerovo Region & 71 & 3.18 & 83 & 54 & 19 \\
\hline Krasnodar Territory & 33 & 3.14 & 84 & 6 & 8 \\
\hline Krasnoyarsk Territory & 69 & 2.90 & 85 & 45 & 9 \\
\hline
\end{tabular}

*\# reg-regions have been sorted alphabetically and numbered. These numbers are used to make the graphing of the results more convenient.

Figure 3 shows various projections for the indicator obtained by calculating the intermediate indices for 'growth', 'inclusion', and 'sustainability' (the three components of the inclusive development index, as presented in Figure 1 and Table 1). According to the graphs, it is obvious that Russian regions are mainly below the average level in terms of inclusion and sustainability, while the growth rates are quite high and above the average. It is also obvious that regions have quite similar performances. This is especially evident in 
the 'inclusion-sustainability' projection. On the one hand, this indicates the levelling of living standards by region; on the other hand, on a number of points, alignment is achieved by offsetting growth with sustainability indicators.

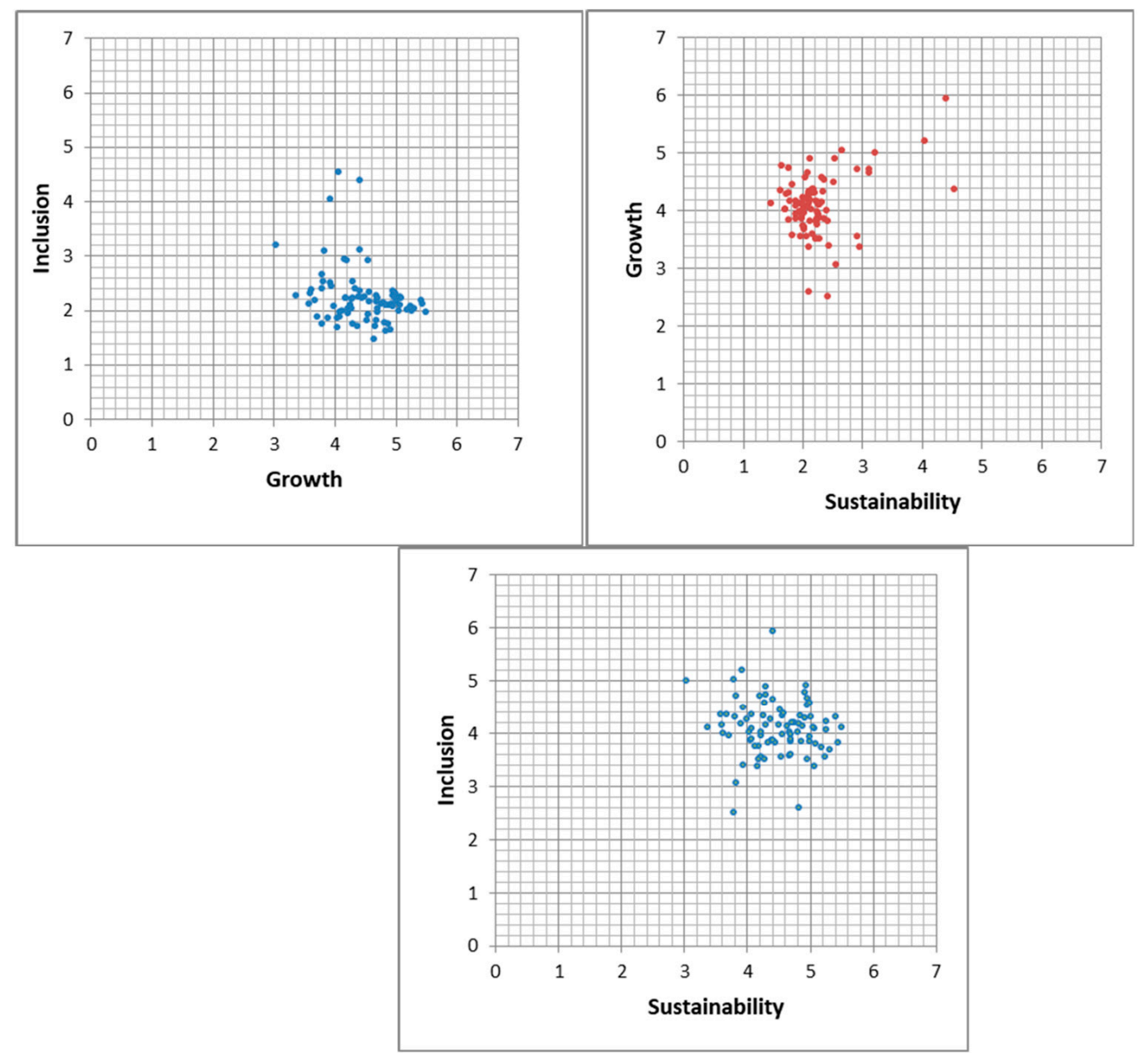

Figure 3. Intermediate indices by the components of the inclusive development index.

The 3D model of the inclusive development index is presented in Figure 4 (for the greater clarity of the vector chart, the values of the components were rationed from 0 to 1 ). 'Inclusion' is along the $\mathrm{X}$ axis, 'growth' is along the $\mathrm{Y}$ axis, and 'sustainability' is along the $\mathrm{Z}$ axis. The graph also shows that despite some deviations for each of the components in a number of regions, most of them are in the mid-value zone.

Finally, the integrated inclusive development index (Figure 5) values are even closer due to the compensatory deviations in a number of regions (high growth and low integration; low growth and high sustainability). This is due to the fact that the most developed industrial regions demonstrate economic efficiency but also environmental disadvantage and income inequality. The least economically developed regions, on the other hand, tend to be more resilient. 


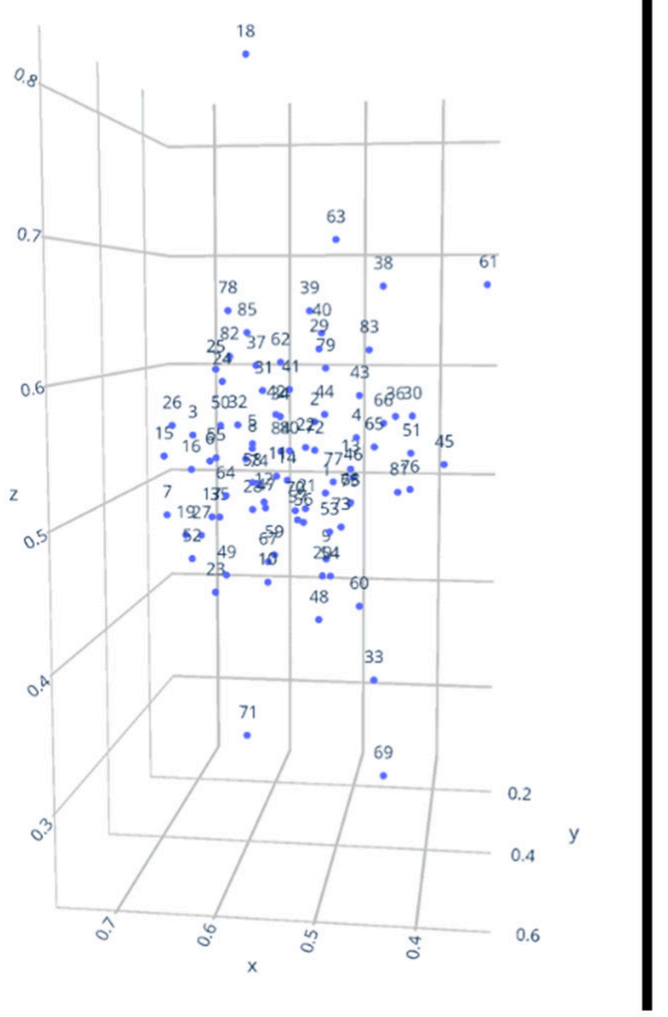

Figure 4. Three-dimensional (3D) model of the inclusive development index of the regions RF by component.

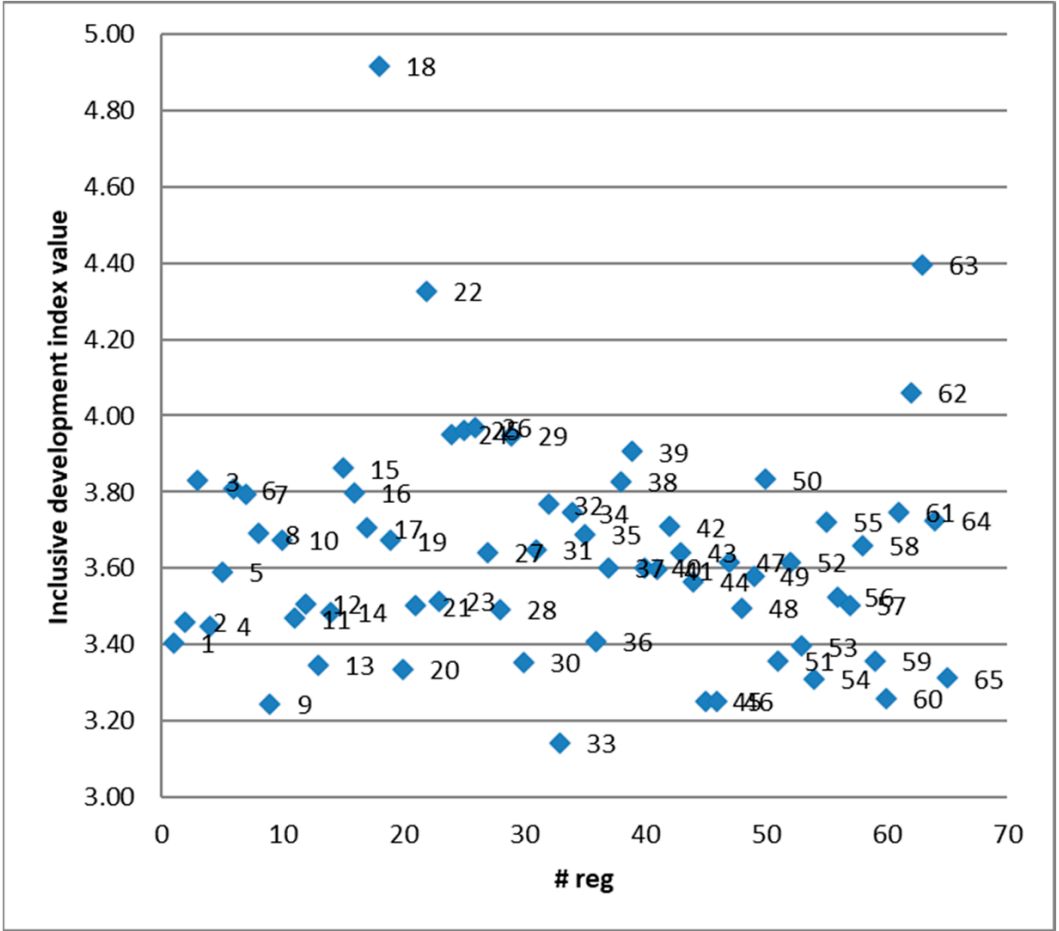

Figure 5. Inclusive development index of the regions of the Russian Federation. 


\section{Discussion and Conclusions}

Thus far, the concept of inclusion and inclusive development has been broadly interpreted. Some studies virtually identify it with sustainable development and growth; others, in contrast, narrow inclusivity down to equal income and a fair distribution [20]. In the first case, i.e., the concept of sustainable development, the emphasis is on the ecofriendliness of economic growth, while in the second case, the emphasis is shifting to the social aspect of economic growth. The recent shift in research from sustainability to social justice/equity can be attributed to the significant recent advances in environmental protection through new technologies and a change in public consciousness not only in developed but also developing economies. In this regard, there is a greater demand for social justice. In addition, the turbulence of the world economy and the resulting adverse social impacts have also contributed to the emergence and development of the concept of inclusivity. However, it is also possible to find a third group of studies considering inclusive development as a concept that reconciles economic, social, and environmental goals for the present generations [7].

The results of this study suggest that at a regional level, there is certainly a significant correlation and interdependence between (ecological) sustainability and inclusion. In this case, we are certainly speaking of sustainable inclusive economic growth and recognising the equal importance of all elements of the modern concept of development: the environment, the economy, and the social sphere. One important contribution of this paper is the adaptation of the WEF methodology at the regional level. An adjusted net savings indicator for the regional level in Russia was not available, so it was important to make the correct adaptation. Therefore, in this paper, a new methodology was proposed based combining the theoretical concept of adjusted net savings and Russian regional statistics. Moreover, this paper calculates the inclusive development index for all regions of Russia. The correct comparison of regions is possible in this case, as is making clusters based on management goals. Therefore, this research adds to the previous research on Russian regions. The paper [40] studies the inclusive development of 16 Russian resource regions, using an adapted version of the indicators proposed by the Asian Development Bank. A more recent study [41] develops a regional inclusive development index that is also close to the proposal of the Asian Development Bank and shows a gap of 2.6 between the most inclusive region (Moscow) and the least inclusive one (the Republic of Tuva). Comparing the results of the only study that uses the WEF at a regional level [41] with those achieved in this paper reveal similar trends. Moscow is the most inclusive region in Russia, and Tuva is one of the less inclusive regions. The results of both assessments are very close, and this could be seen as a corroboration of the quality of the approach proposed in this paper.

Therefore, inclusiveness is a relevant part of the concept of sustainable development. However, this does not mean that it is impossible or unnecessary to study a separate inclusive component. For some countries, such as Russia, this component is currently crucial to achieving truly sustainable development and economic growth. This is also evidenced by the results of the inclusive development index shown in Table 2: there are significant differences in the regions' distribution based on the inclusive development index and GRP. There are also differences between the inclusive development index and the quality-of-life ranking, which are due to the specifics of the methodology for calculating the inclusive development index. These specifics of this methodology are aimed at combining the indicators of economic development, social justice, and environmental sustainability at the regional level.

The results also show minor differences in the level of inclusive development across Russian regions. This may be due to the policy of levelling the living standards throughout the country over the past decades. It could also be partially explained by the specificities of the statistical database used in the study, because it is known that Russia has its own methodology for collecting and processing statistical information, which differs from the methodologies used in other countries. Despite the fact that most regions are in the middle zone of the inclusive development index, it is still possible to differentiate regions and 
identify separate groups. For example, Moscow and the mining autonomous districts (Yamalo-Nenets, Khanty-Mansi, and Nenets) stand out in terms of inclusiveness because they are characterised by high GRP, the modernisation of fixed assets, and higher and more even incomes among the population. Similarly, the group of regions with a low level of inclusiveness includes old industrial regions, with a high level of depreciation for fixed assets, high unemployment, low incomes, and other social problems, as well as the agricultural regions of the Russian Federation.

The analysis of the inclusive development index presented in this paper successfully complements other research types and methodologies; therefore, the researchers plan to continue the calculation of the index by region using dynamics, as well as to conduct a cluster analysis on the basis of the available data for a more precise region segmentation based on their levels of sustainable development, including inclusion.

It is possible to use the results of the analysis to adjust regional development strategies and regional socio-economic policies in Russian regions. We could divide all regions into three groups based on economic problems, social problems, and environmental problems. This could help the federal authorities to differentiate regional policies and pay more attention to specific projects in these territories. In addition, we could extract the regions with the lowest level of inclusive development and create specific programs for them.

Author Contributions: Conceptualisation, E.R., S.G. and C.S.; methodology, E.R.; validation, E.R. and C.S.; formal analysis, S.G.; investigation, E.R.; resources, E.R.; data curation, E.R.; writing-original draft preparation, S.G.; writing-review and editing, C.S.; visualisation, E.R.; project administration, S.G.; funding acquisition, S.G. and E.R. All authors have read and agreed to the published version of the manuscript.

Funding: This research was funded by the Academic Excellence Project 5-100 proposed by Peter the Great St. Petersburg Polytechnic University.

Informed Consent Statement: Not applicable.

Data Availability Statement: Publicly available datasets were analysed in this study. These data can be found here: [https://gks.ru/bgd/regl/b20_14p/Main.htm].

Conflicts of Interest: The funders had no role in the design of the study; the collection, analysis or interpretation of data; the writing of the manuscript or the decision to publish the results.

\section{References}

1. WEF. The Inclusive Development Index 2018 Summary and Data Highlights, Report. 2018, p. 14. Available online: http:/ / reports. weforum.org/the-inclusive-development-index-2018/files/2018/10/2018-Inclusive-Development-Index-FULL.pdf (accessed on 22 July 2020).

2. Stiglitz, J.E.; Fitoussi, J.-P.; Durand, M. Beyond GDP; OECD: Paris, France, 2018.

3. Kubiszewski, I.; Costanza, R.; Franco, C.; Lawn, P.; Talberth, J.; Jackson, T.; Aylmer, C. Beyond GDP: Measuring and achieving global genuine progress. Ecol. Econ. 2013, 93, 57-68. [CrossRef]

4. Coscieme, L.; Mortensen, L.F.; Anderson, S.; Ward, J.; Donohue, I.; Sutton, P.C. Going beyond Gross Domestic Product as an indicator to bring coherence to the Sustainable Development Goals. J. Clean. Prod. 2020, 248, 119232. [CrossRef]

5. Gupta, J.; Pouw, N.R.M.; Ros-Tonen, M.A.F. Towards an elaborated theory of inclusive development. Eur. J. Dev. Res. 2015, 27, 541-559. [CrossRef]

6. van Gent, S. Beyond Buzzwords: What Is "Inclusive Development"? Synthesis Report. INCLUDE-Knowledge Platform on Inclusive Development Policies. August 2017. Available online: https://includeplatform.net/wp-content/uploads/2017/09/B eyond-buzzwords.pdf (accessed on 22 July 2020).

7. Commission on Growth and Development. The Growth Report: Strategies for Sustained Growth and Inclusive Development; World Bank: Washington, DC, USA, 2008. Available online: http:/ /hdl.handle.net/10986/6507 (accessed on 22 July 2020).

8. World Bank. Inclusive Green Growth; World Bank: Washington, DC, USA, 2012. [CrossRef]

9. Scottish Government. Scotland's Economic Strategy; The Scottish Government: Edinburgh, UK, 2015.

10. Samans, R.; Blanke, J.; Corrigan, G.; Drzeniek, M. The Inclusive Growth and Development Report; World Econ. Forum, World Economic Forum: Geneva, Switzerland, 2017. Available online: http://www3.weforum.org/docs/Media/WEF_Inclusive_Grow th.pdf (accessed on 23 July 2020).

11. Skhvediani, A.; Kudryavtseva, T. The Socioeconomic Development of Russia: Some Historical Aspects. Eur. Res. Stud. J. 2018, XXI, 195-207. [CrossRef] 
12. Razinkina, E.; Pankova, L.; Trostinskaya, I.; Pozdeeva, E.; Evseeva, L.; Tanova, A. Student satisfaction as an element of education quality monitoring in innovative higher education institution. In Proceedings of the E3S Web of Conferences, Semarang, Indonesia, 15-16 August 2017; p. 03043.

13. Khadra, J.B.; Goncharova, N.L.; Radwan, Y. Regional aspects the small and medium enterprises and their impact on the social and economic development. In Proceedings of the 33rd International Business Information Management Association Conference, IBIMA 2019: Education Excellence and Innovation Management through Vision 2020, Granada, Spain, 10-11 April 2019.

14. Gutman, S.; Rytova, E.; Kravchenko, V. System of regional indicators for sustainable development of the far North regions. In Proceedings of the 31st International Business Information Management Association Conference, IBIMA 2018: Innovation Management and Education Excellence through Vision 2020, Milan, Italy, 25-26 April 2018.

15. Agnew, J. From the political economy of regions to regional political economy. Prog. Hum. Geogr. 2000, 24, 101-110. [CrossRef]

16. Rodionov, D.G.; Kudryavtseva, T.J.; Skhvediani, A.E. Human development and income inequality as factors of regional economic growth. Eur. Res. Stud. J. 2018, 21, 323-337.

17. Herrschel, T.; Newman, P. Cities as International Actors; Palgrave Macmillan: London, UK, 2017.

18. UN-HABITAT. The New Urban Agenda; United Nations: New York, NY, USA, 2016; pp. 175-195.

19. World Bank. Promoting Inclusive Growth by Creating Opportunities for the Urban Poor; World Bank: Washington, DC, USA, 2017.

20. Lupton, R.; Rafferty, A.; Hughes, C. Inclusive Growth: Opportunities and Challenges for Greater Manchester. 2016. Available online: https://www.manchestercommunitycentral.org/sites/manchestercommunitycentral.co.uk/files/IGAUGreaterManc hesterReport.pdf (accessed on 22 July 2020).

21. Leeds City Council. Leeds Inclusive Growth Strategy; Leeds City Council: Leeds, UK, 2018.

22. Badgaiyan, B. Measuring Inclusive Growth. SSRN Electron. J. 2011, 24. [CrossRef]

23. Turok, I. Inclusive Growth. Handbook of Local and Regional Development; Routledge: London, UK, 2015; pp. 1-20. [CrossRef]

24. Piketty, T. Capital in the 21st Century; Routledge: London, UK, 2018; pp. 43-48.

25. Heshmati, A.; Kim, J.; Wood, J. A Survey of Inclusive Growth Policy. Economies 2019, 7, 65. [CrossRef]

26. Zenkova, I.; Sarvari, R. Human capital in the system of inclusive economic growth. Vestn. PSU Part D Econ. Law Sci. 2019, 6, 14-17.

27. Shelest, S.A. Problems in measuring inclusive economic growth in Russia and CIS countries. Russ. Trends Prospect. Dev. 2017, 12-1, 517-520.

28. Ali, I.; Son, H.H. Defining and Measuring Inclusive Growth: Application to the Philippines; ERD Working Paper Series; The Asian Development Bank (ADB): Metro Manila, Philippines, 2007; pp. 1-44.

29. Khan, A.; Khan, G.; Safdar, S.; Munir, S.; Andleeb, Z. Measurement and Determinants of Inclusive Growth: A Case Study of Pakistan (1990-2012). Pak. Dev. Rev. 2016, 55, 455-466. [CrossRef]

30. Kacem, S.; Abid, L.; Ghorbel-Zouari, S. Measurement of inclusive growth: Evidence from Tunisia. Econ. Dev. 2019, 18, 19-33. [CrossRef]

31. Oshota, S.O. Technology Access, Inclusive Growth and Poverty Reduction in Nigeria: Evidence from Error Correction Modeling Approach. Zagreb Int. Rev. Econ. Bus. 2019, 22, 1-21. [CrossRef]

32. Neagu, O.; Teodoru, M.C. The Economic Competitiveness and Inclusive Development Nexus: Empirical Evidence from 101 Economies. Stud. Univ. Vasile Goldis Arad-Econ. Ser. 2018, 28, 1-19. [CrossRef]

33. Neagu, O. Disparities regarding competitiveness, human capital and inclusive development in the EU: A cluster analysis. Analele Univ. Constantin Brâncuşi din Târgu Jiu Ser. Econ. 2019, 61-71.

34. McKinley, T. Inclusive Growth Criteria and Indicators: An Inclusive Growth Index for Diagnosis of Country Progress; The Asian Development Bank Working Paper; The Asian Development Bank (ADB): Metro Manila, Philippines, 2010; pp. 1-34.

35. Cichowicz, E.; Rollnik-Sadowska, E. Inclusive Growth in CEE Countries as a Determinant of Sustainable Development. Sustainability 2018, 10, 3973. [CrossRef]

36. Sun, C.; Liu, L.; Tang, Y. Measuring the Inclusive Growth of China's Coastal Regions. Sustainability 2018, 10, 2863. [CrossRef]

37. Sun, Y.; Ding, W.; Yang, Z.; Yang, G.; Du, J. Measuring China's regional inclusive green growth. Sci. Total Environ. 2020, 713, 136367. [CrossRef]

38. Sharafutdinov, R.I.; Akhmetshin, E.M.; Polyakova, A.; Gerasimov, V.O.; Shpakova, R.; Mikhailova, M.V. Inclusive growth: A dataset on key and institutional foundations for inclusive development of Russian regions. Data Brief 2019, 23, 103864. [CrossRef]

39. Sharafutdinov, R.I.; Izmailova, D.O.; Akhmetshin, E.M. Examination of the national key performance criteria of inclusive growth and regional development of the Russian Federation. Theor. Appl. Econ. 2018, 3, 118-134. [CrossRef]

40. Sevastyanova, A.Y.; Tokarev, A.N.; Shmat, V.V. Peculiarities of Applying the Inclusive Development Concept for Resource Regions. Reg. Res. Russ. 2018, 8, 101-109. [CrossRef]

41. Mikheeva, N. Qualitative aspect of the regional growth in Russia: Inclusive development index. Reg. Sci. Policy Pract. 2020, 12, 611-626. [CrossRef]

42. OECD. All on Board; OECD: Paris, France, 2015.

43. UNDP. Strategy for Inclusive and Sustainable Growth; United Nations: New York, NY, USA, 2017; pp. 1-147.

44. European Commission. Europe 2020: Europe's Growth Strategy; European Commission: Luxembourg, 2013. [CrossRef]

45. Asian Development Bank. Asian Development Bank 2018 Annual Report; Asian Development Bank: Manila, Philippines, 2018. 
46. Rauniyar, G.; Kanbur, R. Inclusive growth and inclusive development: A review and synthesis of Asian Development Bank literature. J. Asia Pac. Econ. 2010, 15, 455-469. [CrossRef]

47. Pacetti, E.G. The Five Characteristics of an Inclusive Economy: Getting Beyond the Equity-Growth Dichotomy, December 13, The Rockefeller Foundation. 2016. Available online: https://www.rockefellerfoundation.org/blog/five-characteristics-inclusive-ec onomy-getting-beyond-equity-growth-dichotomy/ (accessed on 24 July 2020).

48. Benner, C.; Pastor, M. Inclusive Economy Indicators-Framework \& Indicator Recommendations. 2016. Available online: https: / / www.rockefellerfoundation.org/wp-content/uploads/Inclusive-Economies-Indicators-Full-Report-DEC6.pdf (accessed on 24 July 2020).

49. World Economic Forum, The Future of Jobs Report 2018. 2018. Available online: http://www3.weforum.org/docs/WEF_Future _of_Jobs_2018.pdf (accessed on 22 July 2020).

50. RSA, Inclusive Growth Commission: Making Our Economy Work for Everyone. 2017. Available online: https://www.thersa.org / discover/publications-and-articles/reports / final-report-of-the-inclusive-growth-commission (accessed on 25 July 2020).

51. GMCA, Stronger Together Greater Manchester Strategy 2013. 2013. Available online: https://www.greatermanchester-ca.gov.u k/media/1683/gm_strategy_stronger_together.pdf (accessed on 23 July 2020).

52. Rafferty, A.; Hughes, C.; Lupton, R. Inclusive Growth (IG) Monitor 2017: Local Enterprise Partnerships; Inclusive Growth Analysis Unit (IGAU), University of Manchester: Manchester, UK, 2017.

53. Hawksworth, J.; Jones, N.C.; Ussher, K. Good Growth. 2011. Available online: https://www.pwc.co.uk/assets/pdf/pwc_good_ growth.pdf (accessed on 25 July 2020).

54. Uskova, T. Regional Sustainability Management; LitRes: Moscow, Russia, 2019.

55. Bobylev, S.N.; Minakov, V.S.; Solovyov, S.V.; Tretyakov, V.V. Ecological-Economic Index of Russian Regions; WWF Russia, RIA Novosti: Moscow, Russia, 2012.

56. Bekish, E.L. Net savings as an indicator of the sustainable development of various types of regions in Russia. Collect. Sci. Pap. SWorld 2011, 13, 91-96.

57. Maschenko, S.O.; Chalaya, V.S.; Drigola, K. Green Housing: Regional Development Policy; Lambert AC: Los Angeles, CA, USA, 2018. 